\title{
sciendo
}

\author{
MICHAŁ CELEJEWSKI ${ }^{1}$, JAKUB PAWLIKOWSKI ${ }^{2}$
}

\section{Hospital network and access to Night and Holiday Patient Care}

\begin{abstract}
Night and Holiday Patient Care is a place providing health services, necessary for securing patients' medical needs in efficient way and round-the-clock. Units providing such care are located in selected hospitals chosen in connection with the introduction of the hospital network since October 1, 2017. The main aim of the study was comparison of changes that occurred in the area of location and access to Night and Holiday Patient Care after and before establishing hospital network. The analysis was based on a review of the relevant legal acts available on the ISAP website, scientific articles selected from the medical databases, as well as information published on the official websites of governmental agencies and entities offering night and holiday medical services. The introduction of the hospital network has changed the number, localization and availability of places providing Nights and Holiday Patient Care. These changes resulted in, on the one side, faster access to more specialized medical care, on the other, a reduction in the number of places in some cities. These changes require monitoring in terms of access and quality of basic care services during nights and holidays, so that in the long-term it can be determined whether the applied changes were beneficial from the perspective of the patient and the health care system.
\end{abstract}

Keywords: Night Patient Care, Holiday Patient Care, hospital network, medical care, public health.

DOI: $10.2478 /$ pjph-2018-0014

\section{INTRODUCTION}

Night and Holiday Patient Care is an ad hoc assistance in the field of primary healthcare opened from Monday to Friday from 6 p.m. to 8 a.m. and round-the-clock on holidays. A person should visit the Night and Holiday Care in case of sudden health deterioration, provided that the patient's state does not endanger his/her life as is in case of ailments, which do not disappear after home or OTC drug treatment or in situations when the patient, in fear of his health, does not want to wait till the opening of the GP's practice. Help can also be obtained on the phone or, in medically justified cases, on a home visit. Because in Night and Holiday Care there is no regionalization, the patient can go to the nearest medical center [1]. In case of serious health damage one needs to contact the nearest Hospital Emergency Department [2]. Recently, Night and Holiday Care has underwent organizational transformations in connection with the introduction of a hospital network based on art. $95 \mathrm{~m}$ section 12 of the Act of 27 August 2004 on health care services financed from public funds (Journal of Laws of 2016, item 1793, as amended) [3] and the Regulation of the Minister of Health of 13 June 2017 [4]. The aim of the article is to present legal regulations in the field of Night and Holiday Patient Care and to analyze the principles and scope of this form of care before and after the introduction of the hospital network.

\section{AIM}

The main aim of the study was comparison of changes that occurred in the area of location and access to Night and Holiday Patient Care after and before establishing hospital network.

The analysis was based on a review of the relevant legal acts available on the ISAP website (Internet System of Legal Acts of the Polish Parliament), scientific articles selected from the Main Medical Library, as well as information published on the official websites of governmental agencies and entities offering night and holiday medical services.

\section{What is a hospital network?}

A hospital network i.e. a system securing primary healthcare services, is a group of hospitals financed from the National Health Fund since October 1, 2017. Medical facilities have been divided into several levels of hospital care coverage. The introduced system consists of three levels of primary health care, two levels of specialized health care and a nationwide level.

The first level of primary health care is mainly provided by county hospitals, the second by larger country and some city hospitals, and the third by regional ones. The specialist level includes pediatric hospitals and selected specialist entities (e.g. oncology or pulmonology). The last level includes national hospitals. Being included in the network is associated with meeting the following conditions: providing medical

\footnotetext{
${ }^{1} 1^{\text {st }}$ Military Clinical Hospital with Polyclinic in Lublin, Poland

${ }^{2}$ Independent Medical Sociology Unit, Faculty of Health Sciences, Medical University of Lublin, Poland
} 
services within an Emergency Room or Hospital Emergency Department under a contract with the Polish National Health Fund for at least two years and having other units as listed in the Act [3].

For first level hospitals, two of the following units are required: general surgery, internal diseases, obstetrics or gynecology, neonatology or pediatrics. In special cases (no other facility providing medical services in a given district or fulfilling $50 \%$ of the contract granted in the previous year) it is sufficient to have only a unit of internal medicine.

To be listed as a second level hospital, it is necessary to have six units from the first level hospital (as above) and 3 units from the second level (pediatric surgery, plastic surgery, cardiology, neurology, ophthalmology, orthopedics, otolaryngology, rheumatology or urology). Exceptionally, hospitals with a plastic surgery unit, general surgery and rehabilitation, a unit of orthopedics and traumatology of movement for children or adults with rehabilitation or a rheumatology unit with rehabilitation may also qualify for the second level.

The third level hospitals have the following units assigned to them: thoracic surgery, thoracic surgery for children, vascular surgery, lung diseases, lung diseases for children, infectious diseases, infectious diseases for children, cardiosurgery, cardiac surgery for children, nephrology, nephrology for children, neurosurgery, neurosurgery for children, children's neurology, children's ophthalmology, orthopedics and traumatology of children, children's otolaryngology, clinical toxicology, clinical toxicology of children, clinical transplantation, clinical transplantology for children and urology for children. A hospital will qualify to the third level if it possesses eight units (out of those listed for all three levels), including at least three third level units. It can also have two units from the third level or two from the first or second level. There exists yet another way to be given a third level. It is by possessing a department of infectious diseases or infectious diseases for children provided that they constitute more than half of all units in the hospital.

TABLE 1. List of required units to be qualified as first, second or third level hospital.

FIRST LEVEL At least two of: general surgery, internal diseases, $\begin{array}{ll}\text { FIRST LEVEL } & \text { obstetrics or gynecology, neonatology or pediatrics } \\ \text { HOSPITAL } & \end{array}$ are required

All units listed above + at least 3 of: pediatric surSECOND LEVEL gery, plastic surgery, cardiology, neurology, ophthalHOSPITAL mology, orthopedics, otolaryngology, rheumatology, urology

8 units required from all levels and at least 3 of:

- thoracic surgery ( + for children),

- vascular surgery,

- lung disease (+ for children),

- infectious diseases (+ for children),

- cardiosurgery (+ for children),

- nephrology (+ for children),

THIRD LEVEL - neurosurgery (+ for children),

HOSPITAL • children's neurology,

- children's ophthalmology,

- orthopedics and traumatology of children,

- children's otolaryngology,

- clinical toxicology (+ for children),

- clinical transplantation, clinical transplantology for children

- urology for children
Specialist hospitals with an oncological profile should include at least six of the following units: brachytherapy, oncological gynecology, chemotherapy with hospitalization, oncological surgery, oncological surgery for children, hematology, oncology and pediatric hematology, clinical oncology, radiotherapy, isotopic therapy, clinical transplantology and clinical transplantology for children. It should provide services in at least one of the gynecological oncology profiles, oncology or oncology surgery for children; have one of the units from brachytherapy, radiotherapy or isotope therapy and one unit from the following: hospitalization chemotherapy, hematology, oncology and pediatric hematology or clinical oncology. There is one additional possibility of qualifying a hospital under the oncological profile. It is the possession of at least three units assigned to this profile, these units must constitute over half of all units in a given hospital. For hospitals with a pulmonological profile, the following units are assigned: chemotherapy with hospitalization, chest surgery, thoracic surgery of children, lung diseases and lung diseases of children. A hospital, in order to qualify for the pulmonological profile, must fulfill at least one of the following requirements: it must have at least two units mentioned above and they must constitute more than half of the total number of units in a given hospital, the value of the unit's contracts for the past year was higher than 20 million zloty or the hospital possesses a department of lung diseases or lung diseases for children and a tuberculosis treatment unit, which accounts for at least $30 \%$ of the value of the annual contract of the entire hospital.

Hospitals that will become part of the hospital network are to provide the patient with access to specialist clinics, enable comprehensive care organized by the hospital and shorten the waiting time for first aid in Hospital Emergency Departments and Intervention rooms. According to the Regulation of the Ministry of Health of June 13, 2017 on determining detailed criteria for qualifying service providers to different levels of the System of Fundamental Hospital Care Coverage, hospitals qualified to the I, II and III level and pediatric facilities are obliged to provide night and holiday medical care. Qualification to the particular level is granted for a period of four years.

It should be underlined that this regulation provides criteria, which should be met by individual entities that are to be qualified for each of the given reference levels. These criteria were established using an analysis of individual types of benefits and their scope. What is more, the comparison of profiles of given entity's security measures was also taken under consideration. It can be stated with a high probability that the reference level of a given entity is determined by its scope of specializations [4].

\section{Night and holiday patient care and the hospital network}

On December 17, 2015 the Minister of Health issued an Announcement regarding the enactment of a uniform text of the Regulation of the Minister of Health on guaranteed services in the field of primary healthcare. Annex 5 of the announcement contains a list of guaranteed services for Night and Holiday Care and the conditions for their implementation. On this basis, the medical services provided directly on the spot, by phone or at the patient's home are the benefits of Night and Holiday Care. Night and Holiday Care services are available from Monday to Friday from 6 p.m. to 8 a.m. and around the clock on Saturdays, Sundays, and holidays. If during a home visit, the patient's state proves to require hospitalization, 
the visiting physician or nurse is required to help until an ambulance arrives [5].

The Regulation of the Minister of Health of 28 June 2017 amending the previous regulation on guaranteed services in the field of primary healthcare entered into force on 1 October 2017. On its basis, employees of the Night and Holiday Patient Care provide medical benefits with unchanged days and hours of service directly on the spot, in the patient's home and on the phone. The patient, based on doctor's recommendations, may also benefit from nursing assistance. Additionally, medical benefits are divided in scope into primary and complementary. The primary scope pertains to situations in which an entity providing assistance as part of Night and Holiday Care guarantees hospitalization benefits in its medical facilities. In comparison, the complementary scope indicates a lack of possible hospitalization after a visit to the Night and Holiday Care. Additionally, due to the need for medical services, the care provider is required to assure a proper amount of medical personnel and equipment needed for efficient patient care [6].

In each of the Night and Holiday Care facilities, there should be at least one doctor-nurse team, all holding the right to practice. Regarding medical aids, each of the entities should have and ECG apparatus, a resuscitation kit with a face mask for replacement breathing, two sets of cell phones with call recording system, Anaphylactic Shock Kit blood pressure measuring device, stethoscope, glucometer with blood glucose level marking strips, otoscope, injection kit, dressing kit, disinfection and disinfectant packs, thermometers and personal protective equipment.

In addition, the service provider must assure appropriate structural conditions, which include: a medical and surgical office, a room for storing medical records and medicines, waiting rooms and sanitary rooms. In addition, at the Night and Holiday Care point there should be a landline telephone, a doctor's couch, a refrigerator, medicine storage cabinet, and a treatment table [7].

\section{DISCUSSION}

Prior to the introduction of the hospital network regulation, the Night and Holiday Care points were not obligatorily linked to the location of the hospital. In general, these were hospitals, outpatient clinics and emergency ambulance stations [8]. However, they did have to meet certain localization criteria i.e. being located within a hospital or have a functional and efficient connection with it. The number of night and hospital care places was dependent on the needs of a certain districts and was established by the director of the Regional Branch of the National Health Fund. The division was made based on territorial areas such as: district, municipality or a designated neighborhood. The provider was chosen based on the results of a contest. An additional condition of providing night and holiday care was having one doctor-nurse team per 50,000 people inhabiting a given area. The time of making provisions remained unchanged [9]. For example, before the introduction of the hospital network, there were 5 places of night and holiday care in Lublin, these included: NZOZ Galen located at Biernacki 9 and Wapowskiego 2/3, NZOZ Luna Med on Aleje Racławickie 23, Medical Center DMP at Projektowa 5 and NZOZ B.D.M Uni-Med. located on Abramowicka 2 [10].
In the Lubelskie province the number of night and holiday care entities remained the same (30 altogether), however, after the changes, Kraśnik and Puławy got one more point (there are currently 2 places in each of the cities) and the city of Lublin lost two.

After the introduction of the Act on the hospital network, 18 entities from the Lubelskie Province were classified to the first, 4 to the second and 5 to the third level of providing emergency care services. Seven hospitals were qualified to the national level. Additionally, there are 2 pulmonological hospitals and 1 oncological one [11].

Based on the Hospital Network regulation, hospitals qualified for the I, II and III level, as well as pediatric facilities are obliged to provide services in the form of night and holiday health care. In case of Lublin, there are only three such hospitals including St. John of God Independent Public Provincial Hospital in Lublin, Stefan Kardynał Wyszyński Province Specialist Hospital (III level) and Prof. Mieczysław Kaczyński Neuropsychiatric Hospital in Lublin (I level). In result, due to the enacted law, Lublin had to close two Night and Holiday Patient Care units because they did not meet the requirements of the Act. Prior to the implementation of the Act, there were five points of Night and Holiday Care and afterwards only three. On the other hand, 2 such units were opened in smaller cities, leaving the number of Night and Holiday Care points overall unchanged.

\section{CONCLUSION}

Project of hospital network was proposed more than ten years ago, but only now has it been implemented (in the revised version) [12]. In creating the hospital network, the Ministry of Health took into account, among others, the location of Night and Holiday Patient Care places, establishing it near Hospital Emergency Departments and Admissions. The aim was to shorten the waiting time for medical assistance and to reduce the number of people waiting for help in the aforementioned departments. Despite minor changes in legal requirements, the location and availability of night and holiday medical services changed. In some places, an example of which is the city of Lublin, the Act caused a reduction in the number of places providing services (from five to three units). Summarizing, the introduction of the hospital network has changed the number, localization and availability of places providing Nights and Holiday Patient Care. These changes resulted in, on the one side, faster access to more specialized medical care, on the other, a reduction in the number of places in some cities. They require monitoring in terms of access and quality of basic care services during nights and holidays, so that in the long-term it can be determined whether the applied changes were beneficial from the perspective of the patient and the health care system. 


\section{REFERENCES}

1. http://www.nfz.gov.pl/dla-pacjenta/nocna-i-swiateczna-opieka-zdrowotna/; [cited 2018 Nov 12]

2. Ustawa z dnia 8 września 2006 r o Państwowym Ratownictwie Medycznym. Dz. U. 2013 poz. 757.

3. Art. $95 \mathrm{~m}$ ust. 12 ustawy z dnia 27 sierpnia 2004 r. o świadczeniach opieki zdrowotnej finansowanych ze środków publicznych (Dz. U. z 2016 r., poz. 1793, z późn. zm.)

4. Obwieszczenie Marszałka Sejmu Rzeczpospolitej Polskiej z dnia 15 września 2017 r. - Dz. U. 2017 poz. 1938

5. Rozporządzenie Ministra Zdrowia z dnia 13 czerwca 2017r - Dz. U. 2017 poz. 1163.

6. Rozporządzenie Ministra Zdrowia z dnia 28 czerwca 2017 roku zmieniające rozporządzenie w sprawie świadczeń gwarantowanych z zakresu podstawowej opieki zdrowotnej - Dz. U. 2017 poz 1300.

7. Obwieszczenie Ministra Zdrowia z dnia 17 grudnia 2015 r. w sprawie ogłoszenia jednolitego tekstu rozporządzenia Ministra Zdrowia w sprawie świadczeń gwarantowanych z zakresu podstawowej opieki zdrowotnej .Dz. U. 2016 poz. 86, załącznik nr 5.

8. Gostyńska M. Nocna i świąteczna opieka zdrowotna - zasady funkcjonowania i obowiązujące procedury Kontrola Państwowa. 2014;59(3):66-78.

9. Zarządzenie Nr 64/2013/DS03 Prezesa Narodowego Funduszu Zdrowia $\mathrm{z}$ dnia 15 listopada $2013 \mathrm{r}$

10. www.nfz-lublin.pl; [cited 2018 Nov 12]

11. http://siecszpitali.mz.gov.pl; [cited 2018 Nov 12].

12. Kuszewski K, Krysińska M, Różycka A. Planowanie sieci szpitali: historia pewnej inicjatywy. Zdr Publ Zarz. 2014;2(12):129-33.
Corresponding author

Dr hab. Jakub Pawlikowski

Independent Medical Sociology Unit, Faculty of Health Sciences

Medical University of Lublin

Staszica 4-6 St., 20-081 Lublin, Poland

E-mail: jakub.pawlikowski@umlub.pl 